\title{
ANALISIS TATA CARA \\ PEMILIHAN, PENYALURAN BANTUAN DAN PENILAIAN KINERJA \\ LEMBAGA KEUANGAN MIKRO DALAM RANGKA PEMBIAYAAN \\ PEMBANGUNAN DAN PENINGKATAN KUALITAS PERUMAHAN \\ SWADAYA DAN PRASARANA LINGKUNGAN
}

\author{
Guswandi*
}

\begin{abstract}
Abstrack : Help of funding in order to facilitate the new development and the improvement/the increase in the quality of self-supporting housing and the development of the infrastructure of environmental means as well as the utility of the public who in broad outline was arranged in State Minister for Public Housing's regulation of No. 08/PERMEN/M/2006 was still being needed by explication and the implementation guide. So was needed by a guidance of the implementation or the guide that was related to his funding, adequate funding and was easy was understood by apparatus and the community that wore him. So was needed a guide who was related to the conduct of the election, the conduct to whom of help and the conduct of the assessment of the achievement of the micro financial agency (LKM) that handled directly to the user's community. This paper was the study as the foundation of the compilation of this guide.
\end{abstract}

Kata Kunci: Permukiman, Lembaga Keuangan Mikro (LKM)

\section{PENDAHULUAN}

\section{Latar Belakang}

Pembangunan perumahan swadaya beserta prasarana, sarana dan utilitas umumnya, jika dilakukan secara sistematis akan memberikan kontribusi langsung terhadap peningkatan kesejahteraan, kesehatan, dan kenyamanan dalam bermukim. Hal ini disebabkan antara lain karena pembangunan perumahan dan prasarana sarana, utilitas umum (PSU) dapat mendorong pertumbuhan wilayah dan ekonomi daerah, mendukung pembangunan sosial budaya dan memberikan kontribusi nyata terhadap peningkatan kualitas lingkungan, pertumbuhan ekonomi, pengentasan kemiskinan dan peningkatan kesejahteraan.

Pembangunan rumah/perumahan dan lingkungan yang pengerjaannya secara swadaya sebenarnya telah berlangsung lama dan pada umumnya dilakukan secara perorangan (individu) maupun kelompok. Pelaksanaannya cenderung untuk memenuhi kebutuhan bermukim maupun berlindung saja tanpa memperhatikan kepentingan pihak lain (umum) maupun lingkungannya, untuk itu pembangunan rumah dan lingkungan secara swadaya ini cenderung menghasilkan lingkungan yang

* Guswandi adalah dosen tetap Fakultas Ekonomi Universitas Krisnadwipayana, Jakarta 
tidak teratur dan menjurus ke lingkungan yang kumuh, semua ini dikarenakan keterbatasan biaya dan sumber daya manusianya (SDM)

Bantuan pembiayaan dalam rangka memfasilitasi pembangunan baru dan perbaikan /peningkatan kualitas perumahan swadaya dan pembangunan prasarana sarana lingkungan serta utilitas umum yang secara garis besar telah diatur dalam peraturan Menteri Negara Perumahan Rakyat No. 08/PERMEN/M/2006 masih diperlukan penjabaran dan pedoman pelaksanaan. Untuk itu dalam rangka menunjang terciptanya lingkungan perurmahan dan permukiman yang layak, sehat dan serasi serta terjangkau dalam pembiayaannya oleh masyarakat yang nantinya akan melaksanakan sendiri (swadaya) dan hal ini biasanya dilakukan di lingkungan masyarakat berpenghasilan rendah, diperlukan suatu petunjuk pelaksanaan atau pedoman yang menyangkut pembiayaannya, pembiayaan yang memadai dan mudah dipahami oleh aparat maupun masyarakat yang memakainya. Untuk itu diperlukanlah suatu pedoman yang menyangkut tata cara pemilihan, tata cara penyaluran bantuan dan tata cara penilaian kinerja lembaga keuangan mikro (LKM) yang menangani secara langsung kepada masyarakat pengguna bantuan.

\section{Maksud}

1. Membantu pemerintah daerah dalam rangka mengatasi persoalan pembiayaan pembangunan dan peningkatan kualitas perumahan dan lingkungan yang layak, sehat dan serasi teratur.

2. Membantu masyarakat khususnya yang berpenghasilan rendah untuk memudahkan dan meringankan mengakses pembiayaan dalam rangka pembangunan rumah, sarana dan prasarana lingkungan dalam upaya meningkatkan kualitas lingkungan perumahan swadaya.

3. Membantu pemerintah daerah dalam melakukan penyaringan/seleksi terhadap lembaga keuangan mikro (LKM) agar berkualitas, tata cara penyalurannya serta menilai kinerjanya (LKM) sebagai calon penyalur dana bantuan.

4. Memudahkan pemerintah daerah dalam menetapkan masyarakat berpenghasilan rendah (MBR) yang layak menerima bantuan pembiayaan pembangunan perumahan dan PSU.

\section{Tujuan}

1. Terpilihnya Lembaga Keuangan Mikro (LKM) yang berkualitas dan kredibel, penyaluran dana bantuan pembiayaan tepat sasaran dan tepat guna.

2. Terciptanya akuntabilitas penyaluran dana bantuan pembiayaan pembangunan perumahan dan prasarana dan sarana, utilitas umum di lingkungan. 


\section{TINJAUAN TERHADAP KEBIJAKAN DAN PERATURAN}

\section{Tipologi Umum Subsidi}

Subsidi sebaiknya merupakan sebuah kebijakan yang paling "akhir" dan digunakan dalam konteks menjadi penghubung atau "jembatan" dengan langkah kebijakan lainnya. Gambaran umum tipologi subsidi perumahan (menurut; Marja Hoek Smith) adalah sebagai berikut :

1. Subsidi Sisi Permintaan dan Sisi Penawaran (Demand side and Supply side Subsidies) seperti subsidi tingkat suku bunga KPR, penghapusan PPN untuk pembelian rumah, pengurangan pajak atas pengambilan KPR, Pengurangan biaya pendaftaran tanah - pengurangan PPN untuk tanah yang digunakan bagi perumahan, Anggaran pemerintah untuk rumah/social housing, subsidi tanah.

2. Subsidi untuk Lokasi Khusus atau untuk Rumah Tangga Khusus.

3. Entitlements or Rationed/Allocated Subsidies.

\section{Kriteria Pemilihan LKM/LKMB}

Dalam pemilihan lembaga yang akan membantu dalam penyaluran dana yang ada tersebut diperlukan beberapa criteria. Berdasarkan rangkuman dari beberapa sumber yang ada, dapat disimpulkan criteria dalam pemilihan LKM/LKMB tersebeut diantaranya adalah:

1. Berbadan Hukum dan telah melaksanakan RAT 1 kali dalam setahun.

2. Memiliki agenda kerja yang jelas

3. Tidak bermasalah

4. Merupakan LKM yang sehat

5. Memiliki sistem pengelolaan dan administrasi yang baik

6. Memiliki prospek yang bagus

Sebagai langkah lanjut dalam mengembangkan kesejahteraan masyarakat melalui pendekatan kelompok ini maka sudah sepantasnya mekanisme pembiayaan kredit mikro perumahan dapat diterapkan melalui kelompok-kelompok masyarakat yang layak menerimanya. Pengembangan kesejahteraan masyarakat melalui penyelenggaraan mekanisme mikro kredit perumahan, dilakukan dengan menggunakan pola pendekatan individu di dalam suatu kelompok. Pola ini digunakan, mengingat secara umum kegiatan ekonomi rakyat memiliki ciri antara lain: Informal : sebagian besar kegiatan ekonomi mikro tidak memiliki payung hukum yang mengaturnya, atau dengan kata lain, berada di luar aturan yang dibuat pemerintah. Kondisi demikian, pada satu sisi memberikan dampak positif karena sektor ekonomi rakyat ini menjadi mudah berkembang dan tidak terpengaruh dengan peraturan yang seringkali justru merugikan. Namun demikian, di sisi lain, sektor informal ini memberikan dampak negatif, yaitu terhambatnya akses bagi masyarakat yang bergerak di sektor ini terhadap pembiayaan keuangan formal.

1. Mobilitas : karena sifatnya yang informal, tidak berada di dalam suatu aturan yang mengikat, maka sektor ini mudah dimasuki dan sebaliknya mudah untuk 
ditinggalkan. Pelaku di sektor ini, seringkali mengandalkan peluang atau trend yang sedang berkembang. Sifat mobilitas ini berlaku di sektor sekunder dan tersier.

2. Sistem Keluarga (Kinship): karena sifatnya yang rigid terhadap perubahan dari luar, maka setiap kegiatan ekonomi di sektor ini, didukung oleh semua anggota keluarga. Hal ini dimaksudkan untuk memperkuat usaha yang dibangun.

3. Mandiri : dari ciri-ciri yang telah disebutkan di atas, kegiatan ekonomi rakyat kemudian dipersepsikan sebagai kegiatan yang high risk dan unbankable. Kondisi inilah yang kemudian memaksa pelakunya, untuk bertahan dengan segala kemampuannya secara mandiri tanpa tersentuh oleh Lembaga (Keuangan) Formal.

\section{Mekanisme Penyaluran Dana}

Secara keseluruhan LKM menirima dana stimulan, menyalurkan dana ke MBR sebagai berikut: "MBR menyampaikan proposal atau RAB memalui KSM ditujukan ke LKM dengan syarat yang telah disepakati, LKM melakukan verifikasi lapangan. Jika memenuhi syarat yang telah ditentukan langsung disetujui masuk daftar tunggu. Tetapi jika tidak memenuhi syarat maka akan ditunda/ditolak".

\section{METODOLOGI}

Uraian metodologi pendekatan secara umum, merupakan suatu bagan alir yang kemudian disebut sebagai kerangka pemikiran (makro), dimaksudkan untuk menemukenali hal-hal yang berkaitan dengan "Penyusunan Pedoman Tata Cara Pemilihan, Penyaluran Bantuan Dan Penilaian Kinerja Lembaga Keuangan Mikro Dalam Rangka Pembiayaan Pembangunan Dan Peningkatan Kualitas Perumahan Swadaya Dan Prasarana Lingkungannya", baik mengenai pendekatan kebijakan maupun pendekatan secara konsepsional berikut penanganannya. Dari konsep pendekatan (kerangka Pemikiran) ini diharapkan sejak awal sudah dapat dipahami bahwa "Penyusunan Pedoman Tata Cara Pemilihan, Penyaluran Bantuan Dan Penilaian Kinerja Lembaga Keuangan Mikro Dalam Rangka Pembiayaan Pembangunan Dan Peningkatan Kualitas Perumahan Swadaya Dan Prasarana Lingkungannya" merupakan suatu kegiatan yang strategis dalam rangka pengembangan dan pembangunan perumahan swadaya.

Secara garis besar studi Penyusunan Pedoman Pemilihan Penyaluran Bantuan dan Penilaian Kinerja LKM dalam Rangka Pembiayaan Pembangunan Baru, Peningkatan Kualitas, Prasarana, Sarana dan Utilitas umum terdiri dari a) kajian awal; b) identifikasi; c) analisis; d) sintesis. 


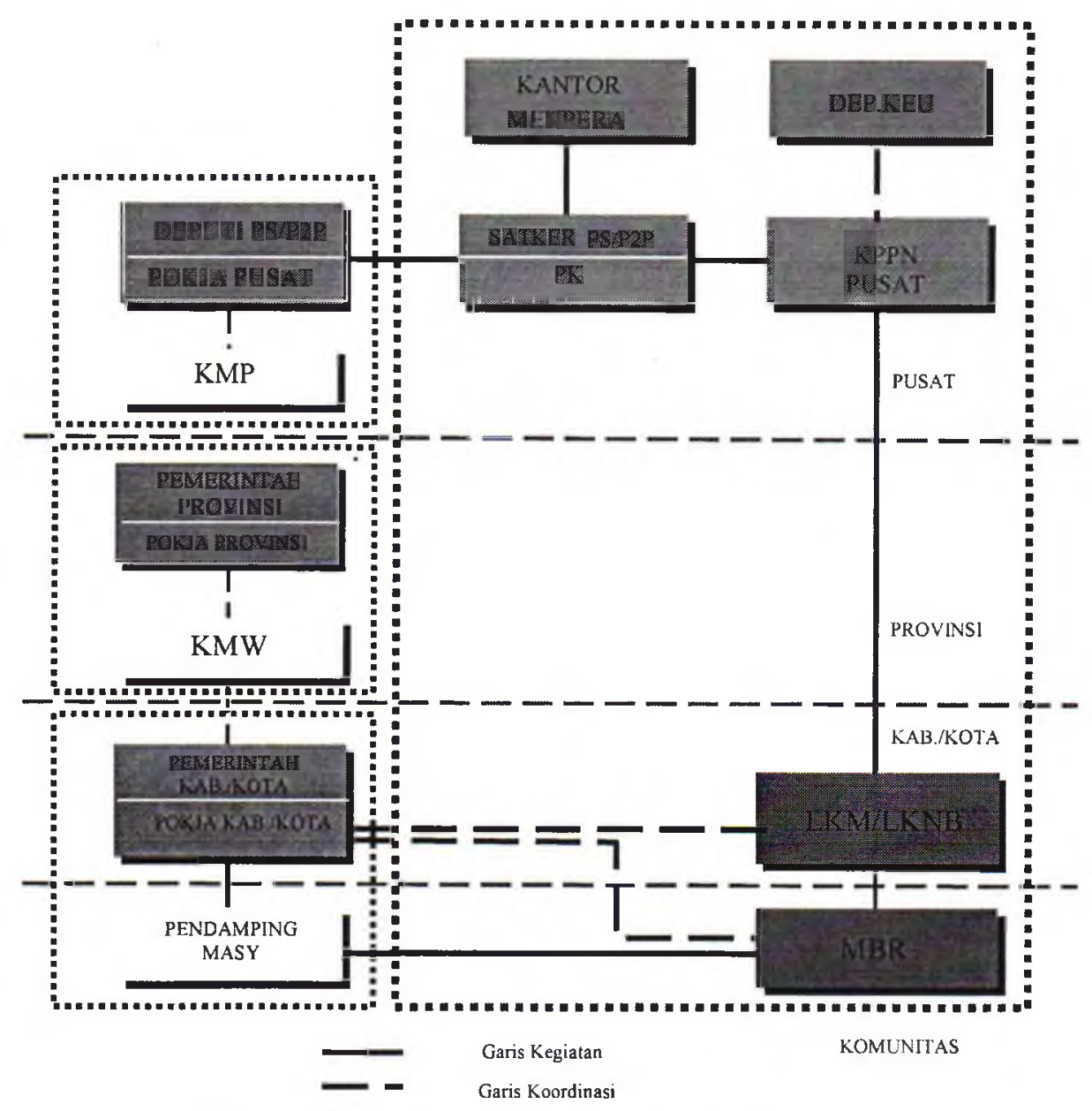

Gambar 1: Mekanisme Penyaluran Dana 


\section{KARAKTERISTIK LKM/LKMB}

Dari tabel di bawh ini dapat dilihat karakteristikLKM/LKMB pada masingmasing wilayah yang dijadikan sebagai lokasi kegiatan studi.

Tabel 1: Karakteristik LKM

\begin{tabular}{|c|c|}
\hline JAWA BARAT & $\begin{array}{l}\text { a. Berbadan Hukum } \\
\text { b. Berpengalaman Mengelola Dana } \\
\text { c. Melakukan RAT } \\
\text { d. Bentuk : Koperasi \& BKM }\end{array}$ \\
\hline BALI & $\begin{array}{l}\text { a. Berbadan Hukum } \\
\text { b. Berpengalaman Mengelola Dana } \\
\text { c. Melakukan RAT } \\
\text { d. Bentuk : KSP, LPD }\end{array}$ \\
\hline JAWA TENGAH & $\begin{array}{l}\text { a. Berbadan Hukum } \\
\text { b. Berpengalaman Mengelola Dana } \\
\text { c. Melakukan RAT } \\
\text { d. Bentuk : KSU }\end{array}$ \\
\hline NTB & $\begin{array}{l}\text { a. Berbadan Hukum } \\
\text { b. Berpengalaman Mengelola Dana } \\
\text { c. Melakukan RAT } \\
\text { d. Bentuk : KSP, KOPWAN }\end{array}$ \\
\hline JAWA TIMUR & $\begin{array}{l}\text { a. Berpengalaman Mengelola Dana } \\
\text { b. Melakukan RAT } \\
\text { c. Bentuk : Koperasi \& BKM } \\
\text { d. Diaudit Internal }\end{array}$ \\
\hline SULAWESI SELATAN & $\begin{array}{l}\text { a. Berbadan Hukum } \\
\text { b. Berpengalaman Mengelola Dana } \\
\text { c. Melakukan RAT } \\
\text { d. Bentuk : LKM, BKM }\end{array}$ \\
\hline
\end{tabular}




\section{ANALISIS PEMBIAYAAN PERUMAHAN SWADAYA}

\section{Kriteria Pemilihan Lkm}

Sesuai dengan Permenpera Nomor : 08/PERMEN/M/2006, hampir semua lokasi kota/kabupaten sample memenuhi kriteria yang disyaratkan dalam pemilihan LKM kecuali LKM di Kabupaten Blitar yang tidak memenuhi kriteria, yaitu : belum berbadan hukum.

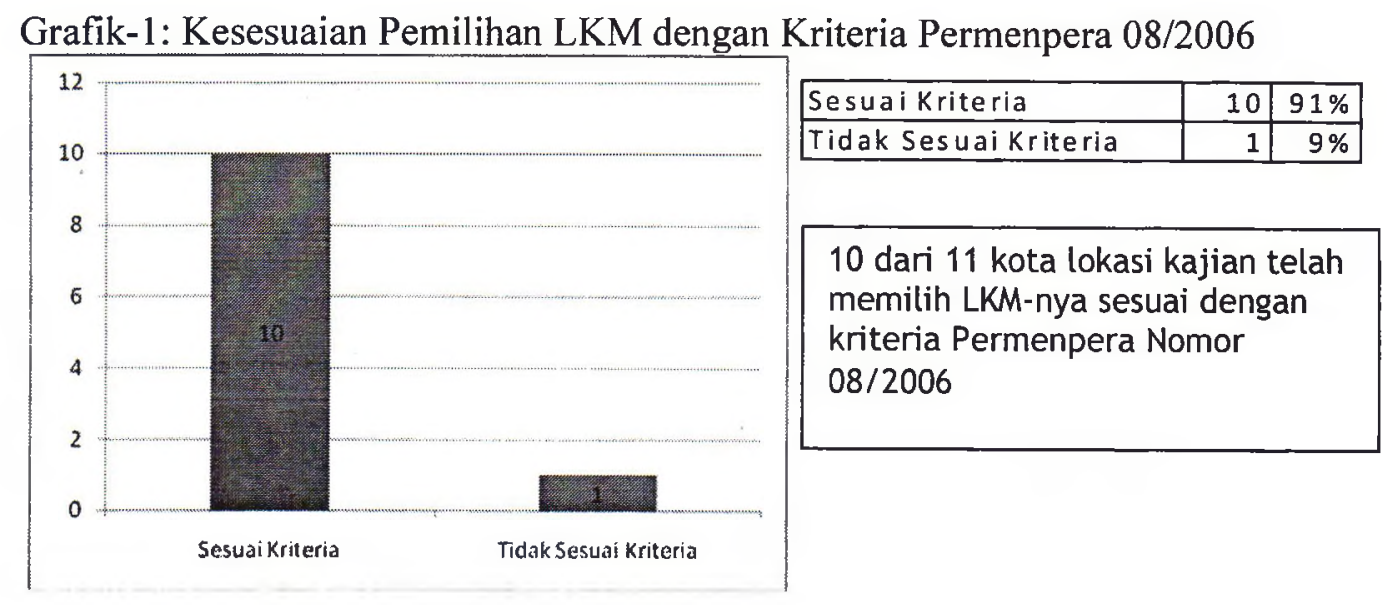

Di beberapa lokasi sampel, selain kriteria yang sesuai dengan Permenpera Nomor : 08/PERMEN/M/2006, juga ada beberapa kriteria tambahan yang dipergunakan. Dari beberapa kriteria yang dimunculkan, terbanyak adalah : kriteria harus sehat. beberapa kriteria tambahan yang muncul adalah: kinerja sehat, kinerja keuangan terbaik, berpengalaman dalam pengelolaan program perumahan dan permukiman, pertimbangan kearifan lokal dan karakteristik daerah

Grafik-2 : Kriteria Tambahan Dalam Pemilihan LKM

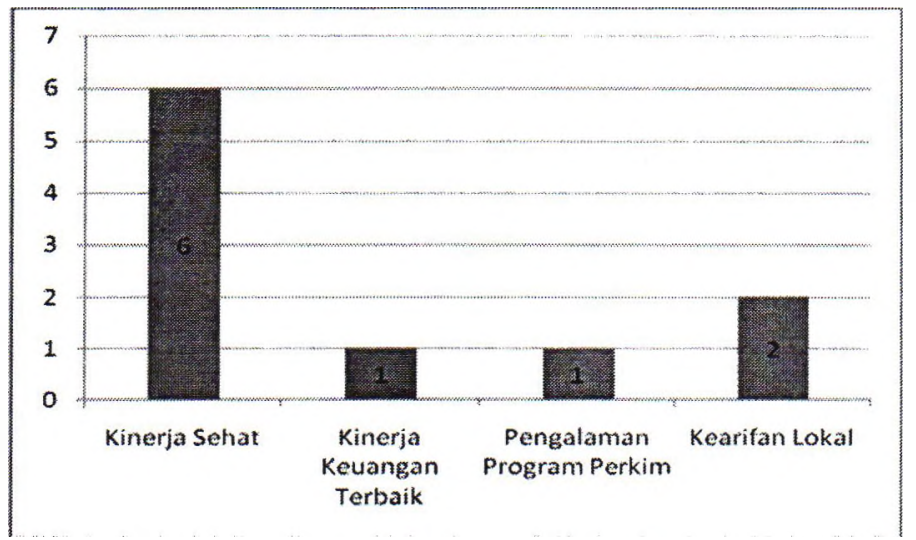

\begin{tabular}{|l|r|r|}
\hline Kinerja Sehat & 6 & $60 \%$ \\
\hline Kinerja Keuangan Terbaik & 1 & $10 \%$ \\
\hline Pengalaman Program Perkim & 1 & $10 \%$ \\
\hline Kearifan Lokal & 2 & $20 \%$ \\
\hline
\end{tabular}

Ada 3 daerah kabupaten/kota yang menambah kriterianya lebih dari 2 kriteria, yaitu : Kab. Bandung, Kota Tasikmalaya dan Kab. Enrekang 


\section{Prosedur (Pola) Pemilihan LKM}

Dari 12 lokasi kota/kabupaten yang menjadi sampel, terdapat 4 varian pemilihan LKM yang dilakukan oleh Pemerintah Daerah masing-masing (dalam hal ini oleh Pokja Kabupaten/Kota), dari mulai yang paling cepat, yaitu dengan menunjuk langsung LKM sampai pada pemilihan melalui kompetisi terbuka yang melibatkan penilaian dari pihak/pelaku lain.

Berbagai kendala yang melatarbelakangi perbedaan prosedur pemilihan LKM yang beragam tersebut di masing-masing Kabupaten/Kota adalah berkaitan dengan persoalan waktu dan keterbatasan informasi (baca : data) yang tidak tersedia, terutama bila dikaitkan dengan LKM yang memiliki pengalaman dalam pengelolaan program perumahan swadaya.

Beberapa prosedur (pola) yang dilakukan di lokasi sampel dalam pemilihan LKM adalah : kompetisi, seleksi / pemilihan oleh pokja , penunjukan

Grafik-3: Prosedur (pola) Dalam Pemilihan LKM di Masing-masing Kab/Kota

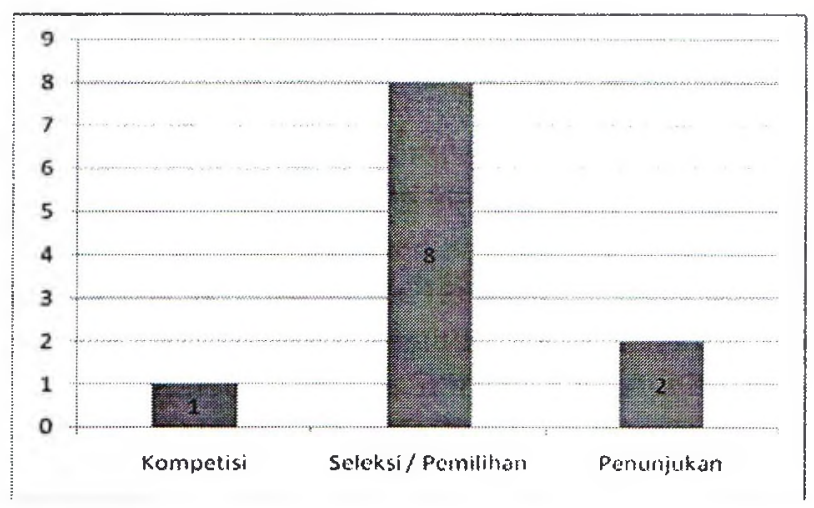

\begin{tabular}{|l|r|r|}
\hline Kompetisi & 1 & $9 \%$ \\
\hline Seleksi / Pemilihan & 8 & $73 \%$ \\
\hline Penunjukan & 2 & $18 \%$ \\
\hline
\end{tabular}

Prosedur pemilihan LKM terbanyak adalah melalui Seleksi dan Pemilihan oleh Pokja, di beberapa daerah seleksi melibatkan pihak lain, misal di Kab. Bandung melibatkan Forum Masyarakat Perumahan Kab. Bandung

\section{Varian Bentuk Lkm Yang Terpilih Di Lokasi Kajian}

Seperti yang disampaikan diatas, kendala keterbatasan waktu dan informasi (data) yang dimiliki oleh pemerintah daerah (pokja), hal ini berdampak pada pemilihan LKM yang cendrung menunjuk lembaga yang sudah dikenal (dibeberapa daerah : lembaga yang dekat dengan pemerintah daerah), kecendrungan lain, walaupun dilakukan pemilihan, seleksi bahkan kompetisi hanya dilakukan pada LKM kelompok tertentu saja, misal : BKM P2KP, UED atau Koperasi. 
Grafik-4: Varian Bentuk LKM Yang Terpilih.

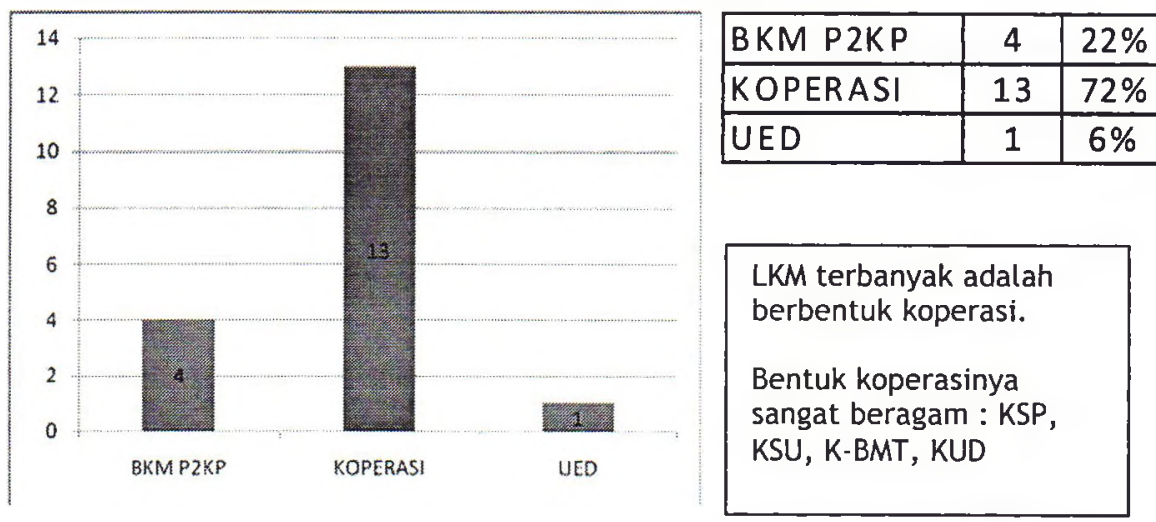

\section{Jumlah LKM Tiap Lokasi Sampel}

Jumlah LKM tiap kota lokasi kabupaten/kota beragam jumlahnya, walaupun hal ini tidak mencerminkan tingkat keberhasilan program di masing-masing kabupaten/kota, tapi ada hal yang perlu dicermati, seringkali LKM menjalankan programnya berdasarkan wilayah kerja administrasinya atau berdasarkan kesamaan profesi dari anggota LKM tersebut, sehingga luasan program dan cakupan pelayanannya perlu dipertimbangkan.

Grafik-5: Jumlah LKM Tiap Kota/Kabupaten.

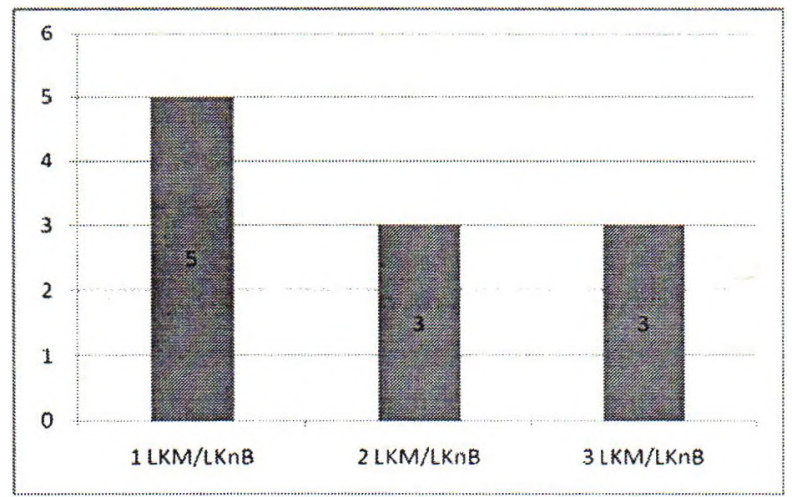

\begin{tabular}{|l|c|c|}
\hline 1 LKM/LKnB & 5 & $45,5 \%$ \\
\hline 2 LKM $/$ LKn B & 3 & $27,3 \%$ \\
\hline 3 LKM/LKnB & 3 & $27,3 \%$ \\
\hline
\end{tabular}

Karena rencana

pengelolaannya tingkat kabupaten, maka untuk

Kabupaten Bandung, ada 1 LKM yang berstatus LKM Pusat dan 13 LKM Lokal (sebagai KSM)

Rekapitulasi dari analisis pemilihan LKM untuk pelaksanaan pemberian stimulan untuk perumahan swadaya bagi masyarakat berpenghasilan rendah (MBR) dapat dilihat pada tabel 2 . 


\section{Analisis Mekanisme Penyaluran Stimulan Menpera}

Mekanisme penyaluran dana stimulan untuk perumahan swadaya bagi masyarakat berpenghasilan rendah (MBR) melalui lembaga keuangan mikro/lembaga keuangan non bank (LKM), pada hakekatnya terbagi dalam 2 kegiatan utama (siklus), yaitu tahap persiapan dan tahap pelaksanaan. Tahap persiapan adalah tahapan yang lebih banyak dilakukan oleh pemerintah daerah (baik pusat maupun daerah kabupaten/kota). Sementara tahap pelaksanaan (merupakan siklus yang lebih banyak di lakukan di masyarakat), tahapan pelaksanaan terdiri dari kegiatan : sosialisasi program, penetapan LKM, pembentukan KSM, usulan kegiatan KSM kepada LKM, verifikasi usulan KSM oleh pokja kabupaten/kota, penyampaian usulan KSM dari pokja kabupaten/kota ke satuan kerja kemenpera, dan penyaluran pemberian stimulan.

Dari 11 lokasi kajian kota/kabupaten, tahapan pelaksanaan di masing-masing lokasi tidak semuanya sama, terdapat varian-varian dan penyesuaian dalam pelaksanaannya. Secara umum dari 11 lokasi kajian masih dirasakan berbagai kelemahan dan hambatan dalam pelaksanaan dari mulai sosialisasi sampai ke penyalurannya.

Di bawah ini akan kami sampaikan ringkasan hasil kajian pelaksanaan penyaluran stimulan, sesuai tahapan dalam Permenpera Nomor 08/2006.

Tebel 3 hasil kajian pelaksanaan penyaluran stimulan, sesuai tahapan dalam Permenpera Nomor 08/2006

\begin{tabular}{|c|c|c|}
\hline No & $\begin{array}{l}\text { TAHAPAN } \\
\text { KEGIATAN }\end{array}$ & HASIL ANALISIS LAPANGAN \\
\hline 1 & $\begin{array}{l}\text { TAHAP } \\
\text { SOSIALISASI }\end{array}$ & $\begin{array}{l}\text { - Sosialisasi dilakukan pada awal kegiatan } \\
\text { - Dari hasil wawancara dengan berbagai pelaku, dari tingkatan pokja provinsi, } \\
\text { kabupaten/kota, LKM dan MBR, kegiatan sosialisasi program dirasa masih kurang } \\
\text { intensitasnya. } \\
\text { - Dibeberapa kota/kabupaten sosialisasi hanya dilakukan pada saat koordinasi program } \\
\text { saja. } \\
\text { - Pada saat sosialisasi program tidak didukung oleh media sosialisasi yang memadai } \\
\text { (poster, brosur, leaflet, booklet, dll) } \\
\text { Beberapa dampak dari sosialisasi yang kurang, dibeberapa lokasi, banyak MBR yang } \\
\text { mundur setelah akad pinjaman dilaksanakan. }\end{array}$ \\
\hline 2 & $\begin{array}{l}\text { TAHAP } \\
\text { PEMILIHAN } \\
\text { LKM }\end{array}$ & $\begin{array}{l}\text { - Seperti telah diuraikan pada bagian 5.1, pelaksanaan pemilihan LKM di tiap daerah } \\
\text { masih belum menggunakan prosedur yang sama, hal ini berkaitan dengan belum } \\
\text { tersedianya pedoman atau tata cara pemilihan LKM yang baku, sehingga hasilnya } \\
\text { beragam dan banyak interpretasi dari masing-masing pokja yang diberi kewenangan } \\
\text { menentukan LKM. } \\
\text { - Verifikasi terhadap kelayakan LKM belum optimal dilaksanakan. } \\
\text { Di beberapa daerah hanya dilakukan dengan penunjukan langsung tanpa seleksi atau } \\
\text { pemilihan dari LKM yang ada. Dengan demikian dikhawatirkan program ini tidak } \\
\text { dikelola oleh LKM yang punya kapasitas. }\end{array}$ \\
\hline 3 & $\begin{array}{l}\text { PEMBENTUKA } \\
\text { N KSM }\end{array}$ & $\begin{array}{l}\text { - Pembentukan KSM dirasakan menjadi kegiatan yang paling sulit oleh LKM, karena } \\
\text { dengan waktu yang singkat harus menjaring klien yang sesuai dengan kriteria MBR } \\
\text { sekaligus layak untuk melakukan perguliran } \\
\text { - Dengan waktu yang ada, pembentukan KSM tidak melalui tahapan dan spirit }\end{array}$ \\
\hline
\end{tabular}




\begin{tabular}{|c|c|c|}
\hline No & $\begin{array}{l}\text { TAHAPAN } \\
\text { KEGIATAN }\end{array}$ & HASIL ANALISIS LAPANGAN \\
\hline & & $\begin{array}{l}\text { pembentukan KSM sesungguhnya, karena pembentukan KSM yang dlakukan lebih } \\
\text { kepada kebutuhan pengelompokan yang disyaratkan, di beberapa lokasi KSM tidak } \\
\text { saling mengenal. } \\
\text { Karena LKM yang terpilih mempunyai karakter kewilayahan atau keanggotaan, maka } \\
\text { anggota KSM menjadi segmentatif, sebatas anggota atau nasabahnya dan tidak } \\
\text { menyebar. } \\
\text { Pemahaman Kriteria MBR dan Rumah Tidak Layak Huni belum merujuk pada aturan } \\
\text { yang sama. } \\
\text { Verifikasi kelayakan anggota KSM (MBR) masih belum optimal (dibeberapa lokasi ada } \\
\text { yang sasarannya tidak tepat) }\end{array}$ \\
\hline 4 & $\begin{array}{l}\text { USULAN } \\
\text { KEGIATAN } \\
\text { KSM KEPADA } \\
\text { LKM }\end{array}$ & $\begin{array}{l}\text { - Karena waktu yang terlalu singkat, usulan pemanfaatan stimulan oleh MBR dibeberapa } \\
\text { lokasi tanpa dilengkapi proposal, kalaupun dengan proposal dirasakan kurang maksimal. } \\
\text { - Usulan PSU belum didasarkan pada prioritas kebutuhan anggota KSM (MBR), usulan } \\
\text { masih diputuskan oleh LKM belum dalam kerangka putusan yang partisipatif. } \\
\text { - Usulan PSU banyak yang tidak mendukung peningkatan kualitas lingkunga anggota } \\
\text { KSM (penerima manfaat PSU tidak sama dengan penerima Dana Stimulan perumahan } \\
\text { swadaya) } \\
\text { Penghitungan usulan proposal dibuat oleh LKM, atau dengan bantuan ahli/tukang } \\
\text { bangunan setempat, sehingga RAB dan gambarnya secara teknis tidak dapat } \\
\text { diperhitungkan secara teknis. } \\
\text { Tidak adanya biaya operasional kegiatan dan dana pembuatan profosal dalam } \\
\text { penyusunan usulan kegiatan ini, seringkali jadi hambatan bagi LKM. }\end{array}$ \\
\hline 5 & $\begin{array}{l}\text { VERIFIKASI } \\
\text { OLEH POKJA }\end{array}$ & $\begin{array}{l}\text { - Verifikasi oleh Pokja Kabupaten/Kota dirasakan belum optimal terutama terhadap } \\
\text { usulan dari KSM yang tidak dilengkapi oleh proposal usulan yang lengkap. } \\
\text { Dibeberapa lokasi kajian, pokja kabupaten/kota hanya melakukan verifikasi dokumen } \\
\text { adm nistrasinya saja, tanpa melakukan verifikasi kondisi lapangannya. }\end{array}$ \\
\hline 6 & $\begin{array}{l}\text { USULAN KSM } \\
\text { DARI POKJA KE } \\
\text { SATKER } \\
\text { KEMENPERA }\end{array}$ & $\begin{array}{l}\text { Karena terlambatnya format-format usulan, usulan yang sudah selesai dikerjakan harus } \\
\text { dilakukan perubahan dan perbaikan serta penyempurnaan-penyempurnaan. } \\
\text { - Dengan adanya revisi, banyak waktu dan biaya yang semakin dirasa membebani LKM }\end{array}$ \\
\hline 7 & PENYALURAN & $\begin{array}{l}\text { - Pola penyaluran dana stimulan sampai ke KSM (MBR) hampir semua berupa dana cash } \\
\text { (uang), kecuali untuk Kabupaten Bandung berupa barang/material. } \\
\text { Akibat dari penyusunan proposal usulan yang tidak optimal, ketika penyaluran, banyak } \\
\text { sekali terjadi perubahan, baik dari komponen maupun besarannya. } \\
\text { - Adanya jeda antara termin } 1 \text { dan termin 2, dibeberapa daerah jadi masalah, } \\
\text { pembangunan jadi terhenti karena menunggu termin ke } 2 \text { cair. } \\
\text { Dibeberapa lokasi banyak anggota KSM yang mengundurkan diri. }\end{array}$ \\
\hline
\end{tabular}

\section{KAJIAN DAN ANALISIS PENILAIAN KINERJA LKM}

Kajian atau analisis penilaian kinerja LKM pada bagian ini lebih ditinjau dari aspek, kelembagaan/hukum, pemberdayaan masyarakat, keuangan/akuntansi dan aspek teknik. 


\section{Aspek Kelembagaan/Hukum}

Pengukuran kinerja merupakan suatu alat manajemen untuk meningkatkan kualitas pengambilan keputusan dan akuntabilitas. Pengukuran kinerja mempunyai makna ganda, yaitu pengukuran kinerja dan evaluasi kinerja. Pengukuran kinerja dilakukan untuk menilai pencapaian tujuan dan sasaran yang telah ditetapkan. Pengukuran kinerja pada umum dititikberatkan pada aspek-aspek sebagai berikut: aspek finansial, aspek kepuasan pelanggan, operasi bisnis internal, kepuasan pegawai, kepuasan komunitas stakeholders/shareholders, dan waktu.

Evaluasi kinerja adalah kegiatan untuk menilai keberhasilan dan kegagalan suatu lembaga dalam melaksanakan tugas dan fungsi yang menjadi tanggungjawabnya. Evaluasi kinerja merupakan suatu proses umpan balik atas kinerja masa lalu yang berguna untuk meningkatkan produktifikas di masa mendatang. Evaluasi kinerja berfungsi untuk: mengetahui tingkat keberhasilan dan kegagalan kinerja suatu lembaga., dan memberikan masukan untuk mengatasi permasalahan yang ada.

Untuk mengetahui tingkat keberhasilan kinerrja LKM dalam melaksanakan tugas dan tanggungjawab dalam pemberian stimulan perumahan suadaya perlu untuk dilakukan penilaian kinerja terhadap LKM. Sesuai dengan Peraturan Menteri Negara Perumahan Rakyat Nomor : 08/PERMEN/M/2006, tugas dan tanggung jawab LKM adalah sebagai berikut :

1. mengusulkan kelompok MBR calon penerima pemberian stimulan kepada pokja kabupaten/kota;

2. menyalurkan pemberian stimulan untuk perumahan swadaya kepada kelompok MBR yang sudah disetujui oleh Pokja Kabupaten/kota;

3. mengkoordinasikan proses penyusunan proposal MBR;

4. memberikan laporan bulanan mengenai pelaksanaan kegiatan serta penyaluran stimulan perumahan swadaya kepada Pokja Kabupaten/kota dan Satuan Kerja Pusat.

Dalam Pasal 33 disebutkan bahwa LKM bertanggungjawab mengenai hal-hal sebagai berikut :

1. proses penyaluran pemberian stimulan untuk perumahan swadaya dan pengawasannya sesuai dengan spesifikasi tugas yang ditetapkan.

2. proses penyaluran pemberian stimulan untuk perumahan swadaya yang dimanfaatkan oleh MBR selama kegiatan berlangsung.

3. keberlanjutan pembinaan dan peningkatan kemampuan kapasitas MBR dalam perbaikan dan pembangunan rumah.

4. akurasi data hasil pengawasan dan monitoring yang dilaporkan.

Salah satu aspek penting dalam penilaian kinerja LKM dalam pemberian stimulan perumahan swadaya adalah penilaian dari aspek kelembagaan. Aspek kelembagaan akan menilai LKM sesuai dengan ketentuan dalam Peraturan Menteri Negara Perumahan Rakyat Nomor : 08/PERMEN/M/2006 tentang Pedoman Pelaksanaan Pemberian Stimulan untuk Perumahan Swadaya bagi Masyarakat 
Berpenghasilan Rendah melalui Lembaga Keuangan Mikro/Lembaga Keuangan Non Bankdilihat, Pasal 22 yang selengkapanya berbunyi :

1. LKM calon penyalur pemberian stimulan untuk perumahan swadaya wajib memenuhi syarat-syarat sebagai berikut :

a. telah berbadan hukum;

b. telah melaksanakan Rapat Anggota Tahunan;

2. LKM yang akan memberikan stimulan untuk perumahan swadaya direkomendasikan oleh Bupati/Walikota.

3. LKM bersedia di audit oleh instansi yang berwenang sesuai dengan ketentuan yang berlaku.

Di samping itu, pada aspek kelembagaan juga akan melihat bagaimana mekanisme kelembagaan LKM dalam menyalurkan pemberian stimulan perumahan swadaya. Dengan demikian penilaian kinerja dari aspek kelembagaan ini secara umum adalah sebagai berikut:

\section{Status badan hukum LKM dan Rekomendasi Bupati/Walikota}

Secara umum LKM yang mendapatkan kepercayaan untuk menyalurkan pemberian stimulan perumahan swadaya melalui badan hukum koperasi. Dari 6 Propinsi wilayah studi hanya Propinsi Jawa Barat yang bukan berbadan hukum koperasi khususnya di Kota Cirebon yang mempercayakan penyaluran pemberian stimulan perumahan swadaya melalui Badan Keswadayaan Masyarakat (BKM) bentukan program $\mathrm{P} 2 \mathrm{KP}$.

Keberadaan koperasi sebagai badan hukum sangat kuat karena dilindungi oleh Undang-undang. Berdasarkan Pasal 1 angka 1 UU No. 25 Tahun 1992, Koperasi adalah badan usaha yang beranggotakan orang-seorang atau badan hukum koperasi dengan melandaskan kegiatannya berdasarkan prinsip koperasi sekaligus sebagai gerakan ekonomi rakyat berdasarkan atas asas kekeluargaan. Koperasi memperoleh status badan hukum setelah akta pendiriannya disahkan oleh Pemerintah melalui Menteri Koperasi dan Usaha Kecil dan Menengah. Menurut Pasal 10, UU No. 25 Tahun 1992, mekanisme pengesahan koperasi adalah sebagai berikut :

1. Untuk memperoleh pengesahan sebagaimana dimaksud dalam Pasal 9, para pendiri mengajukan permintaan tertulis disertai akta pendirian Koperasi.

2. Pengesahan akta pendirian diberikan dalam jangka waktu paling lama 3 (tiga) bulan setelah diterimanya permintaan pengesahan.

3. Pengesahan akta pendirian diumumkan dalam Berita Negara Republik Indonesia.

Dari studi lapangan yang kami lakukan, semua koperasi yang menjadi penyalur pemberian stimulan perumahan swadaya telah mendapatkan pengesahan dari Menteri Koperasi dan Usaha Kecil dan Menengah. LKM tersebut telah mendapatkan pengesahan lebih dari 2 tahun sehingga telah menyelenggarakan RAT sekurang-kurangnya 1 kali. Dengan demikian LKM yang berbentuk koperasi ini telah sesuai dengan persyaratan penyalur dalam program ini sebagaimna tercantum dalam 
Pasal 22 ayat (1) Peraturan Menteri Negara Perumahan Rakyat Nomor : 08/PERMEN/M/2006.

Dalam UU Koperasi disebutkan bahwa koperasi bertujuan memajukan kesejahteran anggota pada khususnya dan masyarakat pada umumnya serta ikut membangun tatanan perekonomian nasional dalam rangka mewujudkan masyarakat yang maju, adil, dan makmur berlandaskan Pancasila dan Undang-Undang Dasar 1945. Hal ini sangat relevan dengan tujuan pemberian stimulan untuk membantu MBR agar dapat menempati rumah dan lingkungan yang layak huni dengan memfasilitasi perbaikan/pembangunan rumah atau perumahan melalui pembiayaan yang mudah diakses oleh MBR. Apalagi dibeberapa Kabupaten/Kota, MBR juga merupakan anggota dari koperasi penyalur itu sendiri.

Berbeda dengan Kabupaten/kota yang lain yang menggunakan koperasi sebagai LKM, Kota Cirebon menunjuk BKM (Badan Keswadayaan Masyarakat) yang merupakan bentukan dari program sebelumnya yang pernah diterima Kota ini yaitu P2KP. Walikota Cirebon merekomendasikan 2 BKM yaitu BKM Kecapi Sejahtera dan BKM Kemuning Sari sebagai penyalur pemberian stimulan perumahan swasaya yang dipilih dari 22 BKM yang terdapat di Kota Cirebon. Penunjukan kedua BKM tersebut melalui SK Walikota Cirebon Nomor : 648/1481 tertanggal 19 September 2006.

\section{Status badan hukum Badan Keswadayaan Masyarakat (BKM) di atas}

Namun demikian baik koperasi maupun BKM, keduanya mendapatkan surat rekomendasi dari Pemmerintah Kabupaten/Kota masing-masing untuk diusulkan sebagai penyalur pemberian stimulan perumahan swadaya yang kemudian ditetapkan oleh Menteri Negara Perumahan Rakyat melalui Keputusan Menteri Negara Perumahan Rakyat Nomor :50/KPTS/M/2006 tentang Penetapan Lembaga Keuangan Mikro (LKM) Kabupaten/Kota sebagai Penerima dan Penyalur Pemberian Stimulan untuk Perumahan Swadaya bagi Masyarakat Berpenghasilan Rendah (MBR) Tahun Anggaran 2006.

\section{LKM dalam Struktur Organisasi Pemberian Stimulan Perumahan Swadaya}

Dalam struktur organisasi pemberian stimulan perumahan swadaya, LKM mempunyai hubungan yang sinergis gengan POKJA Kabupaten/Kota sebagaimana diatur dalam Pasal 20 PERMENPERA Nomor : 08/PERMEN/M/2006. Hubungan tersebut tergambarkan dalam struktur organisasi pemberian stimulan perumahan swadaya.

Dalam struktur organisasi tersebut, setelah LKM ditetapkan oleh Menteri Megara Perumahan Rakyat sebagai penerima dan penyalur pemberian stimulan perumahan swadaya, maka LKM hubungan koordinasi dengan POKJA Kabupaten/Kota, hubungan kegiatan dengan Masyarakat Berpenghasilan Rendah 
(MBR) dan hubungan pertanggungjawaban kepada Menteri Negara Perumahan Rakyat/POKJA Pusat baik melalui POKJA Kabupaten/Kota maupun secara langsung.

Koordinasi dengan POKJA Kabupaten/Kota dilakukan berkenaan dengan sinergisitas program pemberian stimulan dengan program pembangunan daerah, pengusulan MBR penerima pemberian stimulan perumahan swadaya, dan laporan penyaluran dana. Sedangkan hubungan kegiatan dengan MBR dilakukan LKM berkaitan dengan penerimaan calon $\mathrm{MBR}$ penerima pemberian stimulan, pembentukan Kelompok Swadaya Masyarakat untuk mempermudah mengkoordinis MBR, penyusunan proposan pengajuan anggaran kegiatan pembangunan/perbaikan rumah, penyaluran bantuan pemberian stimulan dan penarikan angsuran dari MBR. Sementara hubungan pertanggungjawab LKM dengan Menteri Negera Perumahan Rakyat merupakan pertanggungjawaban LKM sebagai penerima dan penyalur pemberian stimulan perumahan swadaya yang harus mempertanggungjawabkan pelaksanaan penyaluran bantuan sosial bergulir.

Secara umum koordinasi LKM dengan POKJA Kabupaten/Kota dapat berjalan dengan baik. Koordinasi ini dilakukan sejak awal pengusulan LKM sebagai penerima dan penyalur pemberian stimulan perumahan swadaya, penyerahan laporan bulanan, penentuan besarnya uang jasa, dan evaluasi kegiatan pemberian stimulan perumahan swadaya. Koordinasi ini sangat menunjang bagi pengendalian kinerja LKM oleh POKJA Kabupaten/Kota sehingga kegiatan yang dilaksanakan dapat berjalan secara sinergis dengan program masing-masing Kabupaten/Kota.

Sedangkan hubungan kegiatan dengan MBR pada umumnya dapat berjalan dengan baik melalui KSM yang beranggotakan MBR berdasarkan kedekatan tempat tinggal. Bahkan dibeberapa Kabupaten/Kota suasana kekeluargaan dalam KSM mampu mendorong semangat kekeluargaan dan gotong royong masyarakat dalam melaksanakan pembangunan.

Sementara hubungan pertanggungjawaban LKM kepada Menteri Negara Perumahan Rakyat/POKJA Pusat pada umumnya masih sangat lemah. Hal ini terlihat dari masih banyaknya keterlambatan LKM dalam menyerahkan laporan bulanan. LKM seringkali menyampaikan laporan bersamaan dengan pengajuan termin pencairan bantuan. Hal ini sangat menyulitkan POKJA Pusat dalam melakukan evaluasi kinerja LKM.

Untuk meningkatkan sinergisitas antara LKM dengan MBR/KSM dan POKJA Kabupaten/Kota perlu diatur secara formal mekanisme evaluasi bersama di tingkat Kabupaten/Kota yang melibatkan ketiga unsur tersebut.

\section{LKM dalam Skema Tahapan Kegiatan Pemberian Stimulan Perumahan Swadaya}

Dalam penyaluran pemberian stimulan perumahan swadaya, LKM mempunyai posisi yang sangat menentukan keberhasilan pelaksanaan program. Dalam tahapan kegiatan, LKM mempunyai tugas dan tanggungjawab untuk mengusulkan lokasi dan kelompok MBR calon penerima pemberian stimulan kepada pokja kabupaten/kota. 
LKM seharusnya memulai melaksanakan kegiatan ini dengan mengadakan sosialisasi kepada masyarakat berpengahasilan rendah mengenai program pemberian stimulant perumahan swadaya dan membuka pendaftaran bagi MBR yang berminat dan sesuai dengan criteria MBR sebagaimana diatur dalam PERMEN No : 08/PERMEN/M/2006. LKM kemudian melakukan verifikasi terhadap MBR yang mendaftar. Hasil verifikasi ini selanjutnya diusulkan kepada POKJA Kabupaten/Kota untuk mendapatkan persetujuan.

Di samping itu, LKM juga bertanggungjawab dalam mengkoordinasikan proses penyusunan proposal MBR. Untuk memudahkan koordinasi dengan MBR LKM membentuk KSM yang beranggotakan MBR yang mempunyai kedekatan lokasi. Melalui KSM inilah, LKM mengkoordinasikan penyusunan proposal MBR. Ppproposal MBR yang dihasilkan selanjutkan diajukan kepada Menteri Negra Perumahan Rakyat melalui POKJA Kabupaten/Kota untuk mendapatkan pemberian stimulant perumahan swadaya.

Setelah mendapatkan persetujuan dari Menteri Negara Perumahan Rakyat, kegiatan selanjutnya adalah penyaluran pemberian stimulant yang sifatnya dana bergulir. Setiap pemberian stimulant kepada MBR, maka LKM melaporkan pelaksanaan penyalurannya kepada POKJA Kabupaten/Kota dan Menteri Negara Perumahan Rakyat/Satker Pusat.

Namun kondisi ideal di atas, tidak dapat dilaksanakan seluruhnya oleh LKM karena waktu pelaksanaan program yang sangat mendesak dan kondisi lingkungan yang tidak memungkinkan. Pelaksanaan program pemberian stimulant perumahan swadaya tahun anggaran 2006 harus menyesuaikan termin anggaran pemerintah, sehingga POKJA Kabupaten/Kota dan LKM hanya memiliki waktu yang sangat singkat (kurang dari satu bulan) untuk melakukan sosialisasi, memverifikasi MBR calon penerima pemberian stimulant perumahan swadaya. Kondisi demikian mengakibatkan pelaksanaan di masing-masing Kabupaten/Kota berbeda-beda. Pada umumnya penentuan LKM dan MBR dilakukan oleh POKJA Kabupaten yang kemudian direkomendasiką kepada Menteri Negara Perumahan Rakyat. Bahkan usulan proposan MBR pada tahap awal juga kurang dikoordinasikan oleh LKM.

Terbatas waktu di atas masih ditambah dengan kondisi lingkungan yang sedang musim hujan di beberapa Kabupaten/Kota dan suasana menjelang hari raya Idul Fitri, sehingga MBR yang seharusnya sesuai dengan criteria merasa kurang berminat untuk mengajukan usulan proposal pembangunan dan perbaikan rumah.

Untuk meningkatkan kinerja LKM dalam skema tahapan kegiatan ini, perlu melakukan perencanaan pelaksanaan program pemberian stimulant perumahan swadaya dengan memperhatikan dan melibatkan partisipasi masyarakat khususnya MBR, LKM, dan POKJA Kabupaten/Kota. Secara khusus LKM harus sejak awal menyiapkan data base mengenai MBR yang memungkinkan dan berminat untuk mengikuti program pemberian stimulant perumahan swadaya. 
3. LKM dalam Mekanisme Penyaluran Pemberian Stimulan Perumahan Swadaya

Dalam mekanisme penyaluran pemberian stimulan perumahan swadaya sebagaimana diatur dalam Pasal 33, LKM bertanggungjawab mengenai hal-hal sebagai berikut :

a. proses penyaluran pemberian stimulan untuk perumahan swadaya dan pengawasannya sesuai dengan spesifikasi tugas yang ditetapkan.

b. proses penyaluran pemberian stimulan untuk perumahan swadaya yang dimanfaatkan oleh MBR selama kegiatan berlangsung.

c. keberlanjutan pembinaan dan peningkatan kemampuan kapasitas MBR dalam perbaikan dan pembangunan rumah.

d. akurasi data hasil pengawasan dan monitoring yang dilaporkan.

Berdasarkan Pasal 29 Peraturan Menteri Negara Perumahan Rakyat Nomor : 08/PERMEN/M/2006, penyaluran pemberian stimulan perumahan swadaya dilakukan dengan mekanisme sebagai berikut :

a. Penyaluran pemberian stimulan untuk perumahan swadaya dilakukan melalui LKM.

b. Penyaluran sebagaimana dalam ayat (1) disalurkan dalam bentuk transfer langsung dari Kantor Pelayanan Perbendaharaan Negara (KPPN) kepada LKM setelah mendapat rekomendasi dari Satker Pusat kepada LKM yang telah ditetapkan.

c. Pemberian stimulan untuk perumahan swadaya diberikan kepada MBR sasaran.

d. Penyaluran stimulan untuk perumahan swadaya dilakukan secara bertahap yaitu

1) tahap pertama $50 \%$ (lima puluh prosen) apabila ada usulan dari masyarakat melalui LKM;

2) tahap kedua $50 \%$ (lima puluh prosen) sisanya apabila pekerjaan telah mencapai $30 \%$ (tiga puluh prosen).

e. Penyaluran stimulan perumahan swadaya sebagaimana dimaksud pada ayat (4) dibuatkan laporan penyaluran sesuai dengan tahapan penyaluran stimulan dan dimanfaatkan sebagai pengendalian untuk menjamin ketepatan penggunaan stimulan untuk perumahan swadaya sebagai pertanggungjawaban dari penerima manfaat (MBR).

Pada pelaksanaan penyaluran, LKM di beberapa Kabupaten/Kota mempunyai cara yang berbeda-beda. Beberapa LKM dalam menyalurkan kepada MBR diserahkan melalui Ketua KSM, tetapi ada juga yang secara langsung diserahkan kepada MBR. Bentuk penyalurannya juga berbeda ada yang langsung diserahkan dalam bentuk uang, tetapi ada juga yang diserahkan dalam bentuk fisik barang bangunan.

Untuk menjamin angsuran dari MBR dibeberapa Kabupaten/Kota ada LKM yang mensyaratkan adanya agunan, tetapi sebagian besar hanya menggunakan jaminan surat pernyataan, dan ada yang memberikan potongan angsuran apabila MBR selama satu tahun tidak pernah telah dalam membayar angsuran.

Meskipun dengan metode yang berbeda-beda tetapi secara substansial penyaluran pemberian stimulan perumahan swadaya dapat dikatakan berhasil, hal ini dapat dilihat rendahnya (kurang dari $10 \%$ ) MBR yang macet dalam membayar 
angsuran. Namun demikian untuk meningkatkan kinerja LKM dan juga untuk memudahkan evaluasi terhadap kinerja LKM dalam menyalurkan pemberian stimulan perumahan swadaya perlu ada standarisasi metode penyaluran, penggunaan agunan, surat pernyataan dan jumlah jasa operasional.

\section{Aspek Pemberdayaan Masyarakat}

Beberapa teori yang menjelaskan tentang Pemberdayaan masyarakat, diantaranya menurut Pranarka dan Vindhyandika, dalam teorinya salah satu kecenderungan yakni kecenderungan sekunder, kecenderungan ini menekankan pada proses pemberian stimulan, dorongan atau motivasi agar individu atau masyarakat mempunyai kemampuan menentukan untuk menentukan kebutuhan.

Ada beberapa strategi pokok dalam pemberdayaan masyarakat yang mempunyai relevansi terhadap kegiatan ini antara lain :

1. Pendekatan kelompok: dengan berkelompok masyarakat miskin mau dan mampu bekerja sama untuk mencapai tujuan yang telah disepakati bersama, berdasarkan kekuatan gerak dari, oleh dan untuk kepentingan mereka bersama,

2. Keswadayaan: sejak penumbuhan kelompok, masyarakat miskin sudah didorong untuk berusaha atas dasar kemauan dan kemampuan mereka sendiri dan tidak selalu tergantung kepada bantuan dan pertolongan dari luar,

3. Kesatuan Keluarga : kepala keluarga beserta anggota keluarga merupakan satu kesatuan untuk kemajuan kesejahteraan mereka, untuk itu peran serta aktif seluruh anggota keluarga sangat diperlukan lebih-lebih anggota keluarga yang perempuan, demikian juga bila kepala keluarganya perempuan,

4. Kemitraan : masyarakat miskin adalah pelaku utama dalam penanggulangan kemiskinan. Untuk meningkatkan efektivitas upaya tersebut perlu membangun kerjasama dengan pemerintah, sektor bisnis dan akademisi sebagai mitra kerja,

Berpijak dari kondisi tersebut Kementerian Negara Perumahan Perumahan Rakyat dalam hal Deputi Bidang Perumahan Swadaya telah menyelenggarakan program pemberian stimulan untuk perumahan swadaya bagi masyarakat berpenghasilan rendah melalui Lembaga Keuangan Mikro/Lembaga Keuangan Non Bank (LKM), dimana kegiatan tersebut merupakan salah satu bentuk kegiatan pemberdayaan masyarakat yang diorentasikan pada perbaikan perumahan dan lingkungan serta sarana dan prasarana lingkungan dengan memanfaatkan sumber daya yang ada untuk mencapai hasil optimal.

Pendekatan yang dilakukan dalam kegiatan ini adalah pendekatan pembangunan yang berkelanjutan dan berbasis pada masyarakat (Comunity Based Suistainable Development). Yang dimaksud dengan pembangunan berkelanjutan adalah pembangunan untuk memenuhi kebutuhan hidup saat ini tanpa merusak atau menurunkan kemampuan generasi mendatang untuk memenuhi kebutuhan hidupnya. Community Based Development merupakan penegasan pentingnya keterlibatan masyarakat dalam proses perencanaan, implementasi maupun evaluasi, sehingga masyarakat selain turut bertanggung jawab terhadap proses pembangunan juga akan 
dapat menikmati hasil pembangunan tersebut. (Acceptable, accountable, transparansi dan suistainable). Dalam pengelolaan bantuan dana stimulan ini yang dikelolah oleh LKM diharapakn adanya keterlibatan masyarakat dalam bentuk pemberdayaan sehingga pengelolaannya dapat lebih transparan dan berkelanjutan, hal ini dimaksudkan agar pengelolaan dana tersebut dapat dilakukan secara bergulir kepada MBR-MBR yang lain yang belum memperoleh kucuran bantuan pembiayaan.

Adapun prinsip-prinsip pengolaan pemberdayaan masyarakat binaan (MBR-MBR yang terhimpun dalam KSM) adalah sebagai berikut :

1. Pilihan kegiatan berdasarkan musyawarah sehingga memperoleh dukungan masyarakat (acceptable).

2. Pengelolaan kegiatan dilakukan secara terbuka dan diketahui oleh masyarakat (Transparant).

3. Pengelolaan kegiatan harus dapat dipertanggung jawabkan kepada masyarakat (accountable).

Pengelolan kegiatan dapat memberikan manfaat kepada masyarakat secara berkelanjutan, baik dalam lingkungan internal maupun eksternal (suistainable).

\section{Aspek Keuangan/Akuntansi}

Pemilihan LKM sebagai pelaksanan penyaluran dana stimulant salah satu syarat yang harus dipenuhi antara lain tentang melakukan administrasi keuangan dan pelaporan keuangan yang dapat diterima oleh khalayak umum, dan berbadan hukum. Pada umumnya LKM yang menerima dana stimulant berbentuk Koperasi.

Pada dasarnya secara keseluruhan LKM pelaksana penyaluran dana stimulant telah melakukan kegiatan administrasi keuangan (akuntansi) walapun masih manual. Para LKM telah melakukan kegiatan administarsi keuangan (akuntansi), diantaranya adalah :

1. Menyusun daftar MBR sebagai anggota KSM, sebagai buku catatan untuk mengetahui jumlah MBR yang layak mendapat dana stimulant, daftar MBR yang telah menerima dana stimulant dan daftar MBR yang belum mendapat dana stimulant (daftar MBR yang menunggu giliran dan stimulan).

2. Memiliki Buku Kas Harian, untuk mencatat penerimaan dana yang berasal simpanan wajib, simpanan pokok dan simpanan sukarela serta untuk mencatat penerimaan dana stimulant. Selain mencatat pemerimanan, LKM juga lekukan mencatat pengeluaran-pengeluaran, sebagaimana umumnya yang telah diatur dalam kegiatan akuntanasi debet dan kredit.

3. Menyusun daftar peminjam atau dafatra piutang. Daftar ini diperguanakn untuk mengetahui jumlah peminjam, jumlah besarnya pinjaman, dan waktu periode jatuh tempo pinjaman.

4. Menyusun daftar Kekayaan/Harta (Assets) Aktiva Tetap yang dimiliki. Digunakan untuk mengetahui Nilai Perolehan/Nilai beli, jumlah jenis aktiva tetap yang dimiliki, umur penggunaan/waktu periode dapat dipergunakan (nilai ekonomis/nilai daya guna) 
5. Sebagian dari LKM memiliki daftar hutang jangka pendek; hutang jangka pendek ini digunakan sebagai dana talangan sementara, untuk memenuhi dana stimulant MBR yang bersifat mendesak.

6. Menyusun buku kegiatan pisik guna mengetahui jumlah, jenis, dan nilai pelaksanaan prasarana dan sarana umum (PSU).

7. Secara keseluruahan LKM belum melaksanakan pelaporan keuangan yang terdiri dari Neraca dan Laporan Laba/Rugi serta Perubahan Modal sebagaimana mestinya seperti Koperasi pada umumnya.

Walaupun secara keseluruhan LKM belum menyajikan laporan keuangan yang terdiri dari neraca dan laba/rugi sebagai alat utama untuk menilai kinerja keuangan LKM pelaksana dana stimulant, tetapi dari kegiatan administarsi keuangan dan kegiatan pisik yang dilakukan, sebagai indikator alat ukur kinerja LKM, dengan cara sebagai berikut :

1. Perubahan Kas dari bulan ke Bulan, mengalami kenaikan, penurunan atau stabil (tetap tidak berubah).

2. Perubahan jumlah MBR penerimana dana stimulant secara absolud maupun persentasi naik, turun atau statis.

3. Apakah terjadi penyimpangan jumlah dan nilai KSU, yakni KSU yang dilaksanakan sesuai atau tidak dengang yang direncanakan.

4. Tingkat kemacetan pelunasan dana stimulant dari MBR berapa persen dari keseluruhan MBR yang ada.

5. LKM memiliki program atau tidak di masa yang akan datang.

Secara organisasi pendelegasian tugas dan kewajiban pengurus telah dilaksanakan dengan tanggung jawab apa belum.

\section{Aspek Teknik}

Bila kita melihat hasil pembangunan, baik rehab maupun pembangunan baru rumah serta pembangunan PSU, penerapan persyaratan teknis bangunan rumah sehat dan layak huni masih banyak yang belum terarah pada penerapan ketentuan teknis.

Beberapa hal yang menyebabkannya adalah : dari sisi perancangan, biasanya anggota KSM merancang sendiri rencana pembangunan rumahnya atau meminta bantuan tukang bangunan, begitupun dengan PSU, LKM biasanya merencanakan sendiri atau dengan menggunakan jasa tukang.

Dari sisi pengawasan, secara teknis pekerjaan pembangunan perumahan swadaya tersebut diawasi oleh tenaga dari LKM yang pada pelaksanaannya banyak yang belum punya kemampuan yang memadai (baik dari sisi pengetahuan maupun pengalamannya)

Terlebih pada saat pembangunan seringkali tidak ada gambar teknis yang mendukung penerapan aspek teknis tersebut.

Beberapa aspek teknis pembangunan yang tidak sesuai dengan standar teknis di beberapa lokasi kajian antara lain : 
1. Jarak antar bangunan, karena terjadi pemadatan ukuran rumah bertambah, dibeberapa lokasi sempadan 0 meter.

2. Faktor Kemanan dan keselamatan bangunan belum menjadi prioritas (bisa dilihat dari kontruksi pondasi dan konstruksi dinding rumah yang dibangun, banyak yang tidak menggukan struktur beton sloof dan kolom)

Faktor estetika dan tampilan masih menjadi prioritas, hal ini sesungguhnya bisa menjadi biaya yang tinggi.

Dalam rangka usulan pembiayaan perumahan swadaya, baik itu usulan untuk pembangunan rumah baru bagi MBR, pelaksanaan renovasi maupun pembangunan Prasarana Umum (PSU). Untuk usulan seperti itu harus memperhatikan aspek teknis yang merupakan bagian dari yang harus dinilai dalam proses pelaksanaan kegiatan tersbeut. Adapun hal-hal yang perlu diperhatikan dalam pelaksanaan konstruksi meliputi beberapa bagian yang terkait didalamnya antaar lain:

1. Persiapan

2. Pelaksanaan fisik dilapangan

3. Pengadaan material

4. Pengadaan alat dan pengendalian tenaga kerja

5. Pengendalian pengeluaran dana

Kelompok Swadaya Masyarakat (KSM) harus melaksanakan kegiatan yang terkait didalamnya secara bersamaan sesuai dengan kebutuhan dilapangan yang dituangkan dalam bentuk : jadwal pelaksanaan, jadwal pengadaan material, dan kebutuhan alat dan tenaga kerja.

Ketua / penanggung jawab KSM harus bertanggungjawab atas kelancaran jalannya kegiatan konstruksi, dibantu oleh satu atau beberapa orang mandor, khususnya untuk pembuatan Prasarana Sarana Utilitas (PSU) dan Pembangunan Baru (PB) yang bersifat komunal. Untuk melaksanakan kegiatan tersebut perlu memperhatikan aspek-aspek teknis sebagai berikut :

\section{Persiapan Pelaksanaan Kegiatan Konstruksi}

Untuk menjamin kualitas pelaksanaan kegiatan, maka perlu adanya persiapan yang matang dan terencana, Persiapan ini lebih ditujukan kepada kesiapan dari aspek Sumber Daya Manusia ( SDM ) baik masyarakat, pengurus dan anggota KSM, Lembaga Keuangan Mikro ( LKM ) dan seluruh pelaku Program Pemberian Stimulan untuk Perumahan Swadaya di tingkat kecamatan maupun kabupaten.

Dengan adanya persiapan diharapkan seluruh unsur pelaku Program Pemberian Stimulan untuk Perumahan Swadaya (PSuPS) dapat melaksanakan kegiatan dilapangan dengan benar dan sesuai dengan hasil yang diharapkan.

Pekerjaan persiapan dapat dilakukan setelah Hasil penetapan usulan yang telah dibuatkan Berita Acara Penetapan Prioritas Usulan kegiatan KSM-MBR. Pekerjaan ini dilakukan oleh KSM dibantu PM dan KMW meliputi : 
a. Menyusun jadwal pelaksanaan secara umum boleh dalam bentuk diagram balok atau kurva $S$.

b. Menyusun rencana pengadaan bahan meliputi pelelangan, jadwal pengadaan, volume pengadaan, mobilisasi bahan, penempatan bahan dan tata cara pembayarannya.

c. Menyusun rencana pengadaan alat, meliputi jadwal pengadaan, mobilisasi dan jumlah alat, penempatan peralatan serta tata cara pembayarannya.

d. Menyusun rencana pengadaan tenaga kerja, meliputi jadwal pengadaan, jumlah tenaga kerja, mobilisasi tenaga kerja, penempatan tenaga kerja, tata cara pembayaran dan pendaftaran tenaga kerja.

e. Menyusun rencana pencairan dana dan Rencana Penggunaan Dana (RPD).

f. Mengadakan pembagian kerja Pengurus KSM - MBR sesuai dengan fungsi dan tugas masing-masing.

g. Memperbaiki patok ukur dan mempersiapkan lahan.

\section{Pelaksanaan Kegiatan Konstruksi}

Pelaksanaan kegiatan konstruksi dilapangan akan dilaksanakan oleh masyarakat sendiri yang dipimpin oleh ketua KSM. Konsultan Manajemen Wilayah ( KMW ) dengan dibantu oleh Pendamping Masyarakat ( PM ) mempunyai tanggungjawab untuk memfasilitasi bagaimana hal ini dapat dilaksanakan dengan baik oleh masyarakat.

Kualitas seluruh prasarana diharapkan cukup baik, sehingga manfaat prasarana tersebut dapat dinikmati dalam jangka waktu yang lama oleh masyarakat, dimana masa pemakaiannya berkaitan erat dengan kualitas konstruksi, operasional prasarana dan pemeliharaannya. Semakin baik konstrusi awal, semakin lama prasarana dapat berfungsi.

Dalam pelaksanaan kegiatan konstruksi dilapangan harus dilakukan beberapa hal, antara lain :

a. Persiapan konstruksi : Persiapan rencana kerja sesuai dengan kebutuhan, baik gambar rencana, jadwal pelaksanaan pengadaan bahan, peralatan serta tenaga kerja. Bila jumlah material sesuai kebutuhan minimal, peralatan dan tenaga kerja telah siap, maka perlu dilakukan rapat pra pelaksanaan konstruksi.

b. Rapat pra pelaksanaan : Dalam rapat pra pelaksanaan, Pendamping Masyarakat dan Konsultan Manajemen Wilayah memberikan pengarahan teknis kepada mandor dan para pekerja bagaimana tatacara pelaksanaan yang diinginkan sesuai dengan petunjuk teknis agar didapat hasil pekerjaan sesuai dengan yang diharapkan. Rapat pra pelaksanaan tersebut direncanakan sesuai dengan target yang akan dicapai, misalnya untuk minggu pertama pekerjaan apa saja yang akan dilaksanakan, siapa yang akan bertanggung jawab terhadap pengadaan tenaga kerja dan siapa yang bertanggung jawab terhadap alat kerja. Hal ini untuk memudahkan pelaksanaan dilapangan dan hasil rapat pra pelaksanaan menjadi 
acuan langkah kerja dilapangan yang telah disepakati bersama antara Pendamping Masyarakat, Konsultan Manajemen Wilayah, KSM dan Mandor.

c. Pelaksanaan konstruksi : Pada saat pelaksanaan konstruksi, para pelaksana harus mematuhi langkah-langkah yang telah disepakati dalam rapat pra pelaksanaan. Apabila kenyataan dilapangan memerlukan perubahan dari rencana, mandor harus melaporkan kepada ketua Tim Pengelola Kegiatan KSM dan dalam hal ini Tim Pengelola Kegiatan mengawasi jalannya pekerjaan pada tiap kegiatan, mengenai apa-apa yang perlu diperbaiki serta mencatat hal-hal yang diperlukan untuk dikonsultasikan kepada PM dan KMW dan sebagai bahan evaluasi dalam pelaksanaan kegiatan selanjutnya.

d. Rapat Evaluasi KSM : Diharapkan dapat dilaksanakan setiap minggu, dimaksudkan untuk mengevaluasi kegiatan konstruksi selama satu minggu berjalan, apakah sudah sesuai dengan yang direncanakan atau apakah kegiatan dilapangan masih belum mencapai target mingguan, maupun apasaja yang menjadi kendala dilapangan, apakah faktor material yang kurang mendukung, peralatan tidak memadai atau mungkin cara kerja dari Tim Pengelola dan masyarakat yang tidak disiplin. Hasil rapat evaluasi harus dapat menghasilkan pemecahan atau jalan keluar untuk mengatasi permasalahan yang terjadi untuk diperbaiki dalam kegiatan konstruksi minggu berikutnya sekaligus dibuat rencana kerja minggu selanjutnya.

e. Dokumentasi Foto : Dokumentasi foto kegiatan prasarana dibuat berdasarkan kemajuan kegiatan yaitu $0 \%, 30 \%$ dan $100 \%$. Dimana pengambilan dokumentasi foto $0 \%, 30 \%$, dan $100 \%$ dilakukan dari sudut atau sisi pengambilan yang sama.

f. Transparansi : Seluruh kegiatan Prasarana Sarana Utilitas (PSU) dan Pembangunan Baru yang bersifat komunal mulai dari survey, perencanaan, pelaksanaan sampai pada tahap pelestarian harus dilakukan secara transparan, Tujuannya diharapkan agar masyarakat turut berpartisipasi membantu, mengawasi dan merasa memiliki terhadap prasarana yang telah dibangun. Transparansi dalam kegiatan pembangunan prasarana dituangkan pada papan informasi.

g. Penyelesaian kegiatan : Yang dimaksud disini meliputi penyelesaian pembangunan prasarana, sebagai bagian dari pertanggungjawaban KSM. Batas waktu penyelesaian ditentukan berdasarkan jadwal yang telah ditetapkan diawal atau ketentuan dari Departemen Keuangan berkaitan dengan batas waktu pencairan dan di KPPN dan atau ketentuan yang dikeluarkan oleh Sekretariat Pusat.

\section{Pengendalian Kualitas Prasarana dan Sarana}

Untuk menjaga kualitas perlu dilakukan tindakan khusus oleh Pendamping Masyarakat (PM). Tindakan khusus yang utama adalah mengharuskan KSM untuk lebih bertanggung jawab dalam pelaksanaan dan lebih transparan kepada masyarakat, 
serta mendorong masyarakat untuk secara aktif turut serta mengawasi dan menjaga kualitas prasarana.

\section{Pengendalian Kualitas Bahan}

Bahan yang dipakai harus memenuhi standar, misalnya untuk bahan semen, besi, pipa dan bahan-bahan pabrikasi lainnya harus sesuai dengan standar Industri Indonesia ( SII ). Tim Pengelola Kegiatan KSM harus selektif dalam pengadaan bahan. Bila Material yang dikirim oleh suplier tidak sesuai dengan pesanan, maka KSM harus menolak bahan tersebut dan minta diganti sesuai dengan pesanan. Pendamping Masyarakat harus selalu memantau kualitas bahan yang akan digunakan.

\section{Pengendalian Dimensi}

Untuk mencapai kualitas pelaksanaan konstruksi yang baik, dimensi atau ukuran prasarana harus selalu dikendalikan sesuai dengan gambar rencana. Untuk menjaga dimensi perlu diperhatikan dan dibahas dari awal sejak rapat pra pelaksanaan.

Bila terjadi perubahan rencana pekerjaan dengan realisasinya khususnya Kegiatan Prasarana Sarana Utilitas (PSU) dan Pembangunan Baru (PB) yang bersifat komunal yang menyebabkan terjadinya pengurangan atau penambahan terhadap volume pekerjaan atau terhadap spesifikasi pekerjaan harus dibuat Berita Acara Revisi.

Pembuatan revisi dimulai dengan pembahasan terlebih dahulu oleh KSM dan hasilnya harus mendapatkan persetujuan dari Pendamping Masyarakat (PM) atau Konsultan Manajemen Wilayah (KMW) serta POKJA Kabupaten / Kota.

Sebelum pelaksanaan pekerjaan yang akan direvisi dimulai, pembuatan revisi harus sudah selesai kemudian dibuat BA Revisi yang dipasang pada papan informasi, dan bila ada penyimpangan, maka pekerjaan dihentikan.

\section{Sop Dan Draft Pedoman}

Penyusunann tata cara pemilihan, penyaluran bantuan dan penilaian kinerja lembaga keuangan mikro dalam rangka pembiayaan pembangunan dan peningkatan kualitas perumahan dan swadaya dan prasarana lingkungannya dituangkan dalam bentuk SOP dan buku pedoman.

\section{DAFTAR PUSTAKA}

Guswandi, 2007. Kajian Aspek Ekonomi dan Manajemen atas Bantuan Stimulan Pembangunan Perumahan Swadaya., Jakarta. Menpera.

Muhtong. 2007. Masukan Teknis Pemberdayaan Kelembagaan Pembiayaan Perumahan Bagi Masyarakat Miskin Perkotaan. Jakarta. Menpera. 
Peraturan Menteri Negara Perumahan Rakyat No: 08/Permen/M/2006 Tentang Pedoman Pelaksanaan Pemberian Stimulan Untuk Perumahan Swadaya Bagi Masyarakat Berpenghasilan Rendah Melalui Lembaga Keuangan Mikro / Lembaga Keuangan Non Bank, Jakarta. Menpera. 


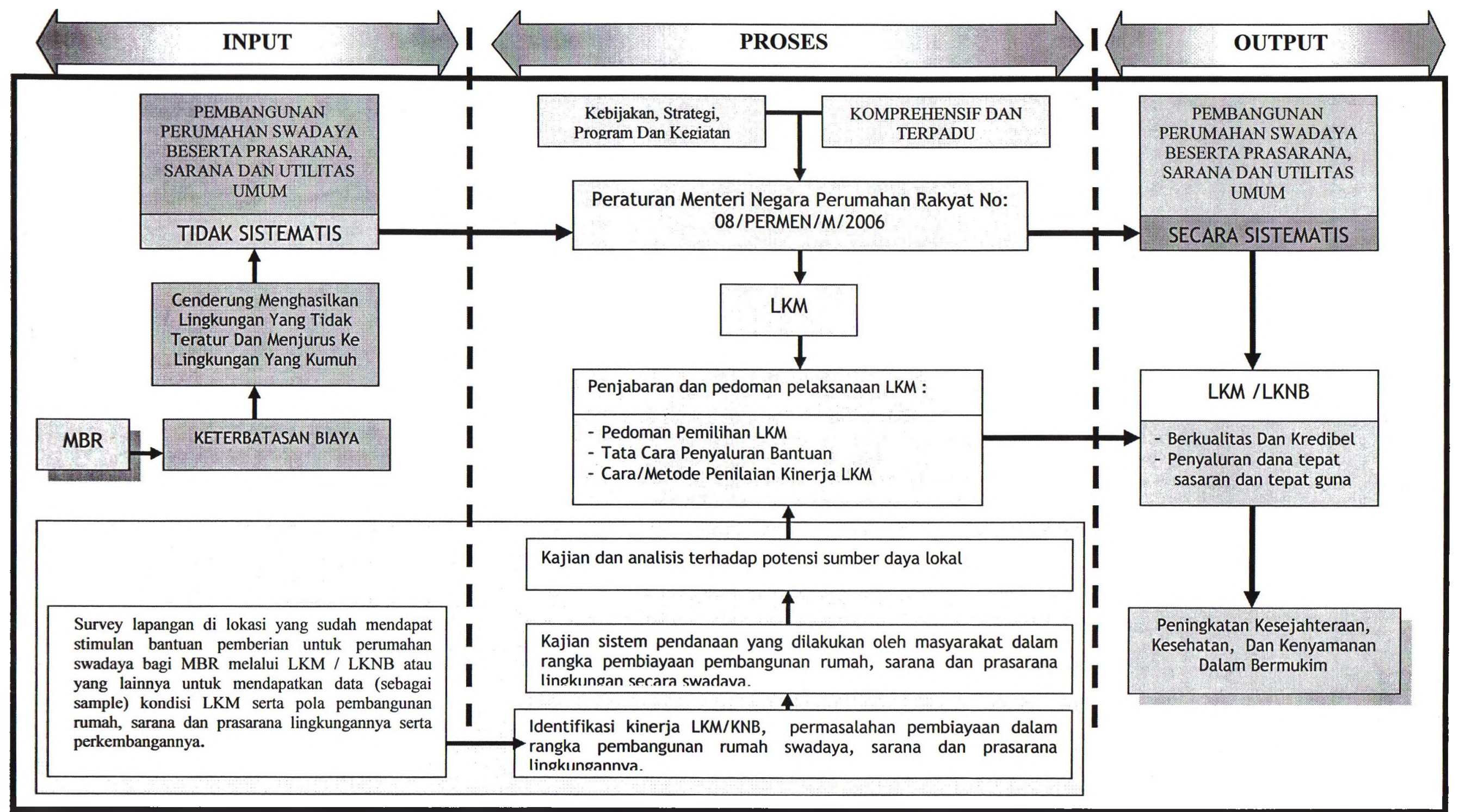

Gambar 2 Kerangka Pemikiran 


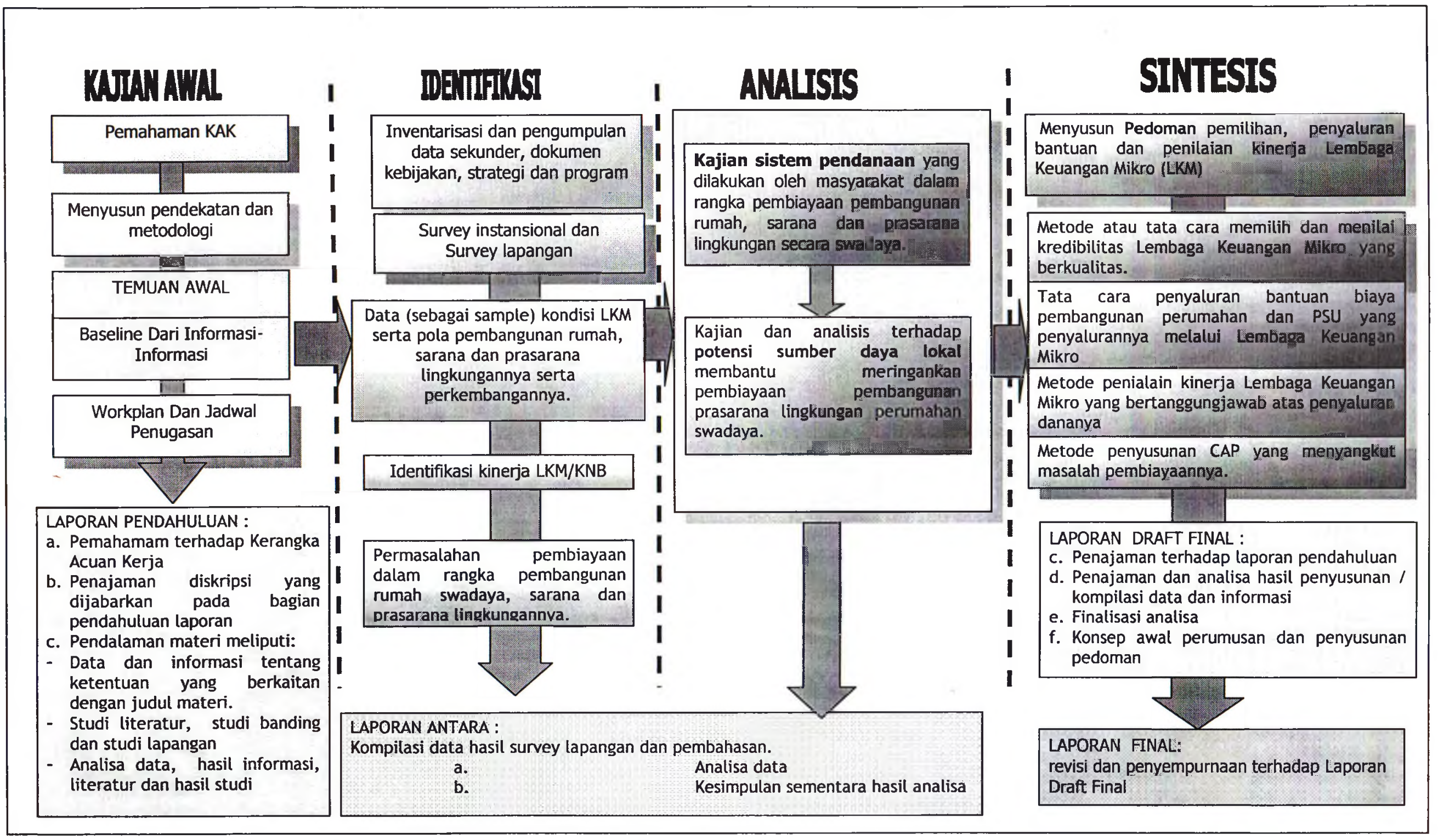

Gambar 3 Metodologi Pekerjaan 
Tabel 2

Perbandingan Pemilihan LKM Dimasing-masing Lokasi

\begin{tabular}{|c|c|c|c|c|c|c|c|}
\hline \multirow[b]{2}{*}{ No } & \multirow[b]{2}{*}{ Item Analisis } & \multicolumn{6}{|c|}{ Lokasi Kajian } \\
\hline & & 1. Kabupaten Bandung & 2. Kota Tasikmalaya & 3. Kota Cirebon & 4. Kota Denpasar & $\begin{array}{l}\text { 5. Kota } \\
\text { Pekalongan }\end{array}$ & $\begin{array}{c}\text { 6. Kota } \\
\text { Purbalinggga }\end{array}$ \\
\hline 1 & $\begin{array}{l}\text { Sesuai Kriteria Permenpera } \\
\text { 08/PERMEN/M/2006: } \\
\text { - Telah Berbadan Hukum } \\
\text { - Telah RAT }\end{array}$ & Sesuai & Sesuai & Sesuai & Sesuai & Sesuai & Sesuai \\
\hline 2 & $\begin{array}{l}\text { Kriteria Tambahan danlam } \\
\text { pemilihan LKM }\end{array}$ & \begin{tabular}{|l|} 
- Koperasi yang sehat \\
- Memiliki Pengalaman \\
Program Perkim \\
\end{tabular} & $\begin{array}{l}\text { - Koperasi yang sehat } \\
\text { - Kearifan Lokal }\end{array}$ & - BKM Paling Sehat & - Koperasi yang sehat & & \\
\hline 3 & Prosedur Pemilihan LKM & $\begin{array}{ll}\text { 1. } & \text { Pokja koordinasi dengan } \\
\text { Dinkop dan FMPKB }\end{array}$ & $\begin{array}{ll}\text { 1. } & \text { Pokja mita data kepada } \\
\text { Dinkop } \\
\text { 2. } \\
\text { Rekomendasi dari } \\
\text { Dinkop } \\
\text { 3. Seleksi oleh Pokja }\end{array}$ & $\begin{array}{ll}\text { 1. } & \text { Pokja koordinasi } \\
\text { 2. } & \text { dengan Forum BKM } \\
\text { 3. } & \text { Kompetisi }\end{array}$ & $\begin{array}{ll}\text { 1. } & \text { Pokja Koordinasi } \\
\text { dengan Dinkop }\end{array}$ & 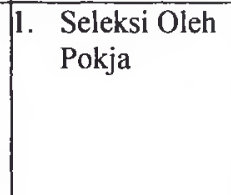 & 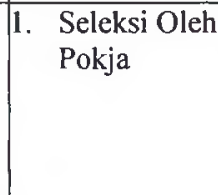 \\
\hline 4 & Bentuk LKM & Koperasi & Koperasi & BKM P2KP & Koperasi & Koperasi & Koperasi BMT \\
\hline
\end{tabular}

\begin{tabular}{|c|c|c|c|c|c|c|}
\hline \multirow[b]{2}{*}{ No } & \multirow[b]{2}{*}{ Item Analisis } & \multicolumn{5}{|c|}{ Lokasi Kajian } \\
\hline & & 7. Kabupaten Banjarnegara & 8. Kota Tulungagung & 9. Kabupaten Blitar & 10. Kota Makasar & 11. Kabupaten Enrekang \\
\hline 1 & $\begin{array}{l}\text { Sesuai Kriteria Permenpera } \\
\text { 08/PERMEN/M/2006 : } \\
\text { - Telah Berbadan Hukum } \\
\text { - Telah RAT }\end{array}$ & Sesuai & Sesuai & Tidak Sesuai & Sesuai & Sesuai \\
\hline 2 & $\begin{array}{l}\text { Kriteria Tambahan danlam } \\
\text { pemilihan LKM }\end{array}$ & & - UED yang sehat & & $\begin{array}{l}\text { BKM Kinerja Keuangan } \\
\text { Terbaik }\end{array}$ & $\begin{array}{l}\text { - KUD yang sehat } \\
\text { - Mewakili Karakteristik } \\
\text { Lokasi }\end{array}$ \\
\hline 3 & Prosedur Pemilihan LKM & 1. Pokja menunjuk LKM & $\begin{array}{l}\text { 1. Pokja melakukan } \\
\text { seleksi dari UED yang } \\
\text { ada }\end{array}$ & 1. Pokja menunjuk LKM & $\begin{array}{ll}\text { 1. } & \text { Pokja melakukan } \\
\text { seleksi LKM } \\
\text { 2. }\end{array}$ & $\begin{array}{l}\text { 1. Pokja mencari referensi } \\
\text { mengenai LKM } \\
\text { 2. Dipilih yang paling sehat }\end{array}$ \\
\hline 4 & Bentuk LKM & Koperasi & UED Simpan Pinjam & Koperasi & BKM & KUD \\
\hline
\end{tabular}

